\title{
Synthesis of 3,5-di-(4-pyridyl)-1 H-1,2,4-triazole
}

\section{Li-Li Liu and Guang Yang *}

Department of Chemistry, Zhengzhou University, Zhengzhou, 450001, China.

* Author to whom correspondence should be addressed. E-mail: yang@zzu.edu.cn; Tel.: +86 37163912869

Received: 3 August 2007 / Accepted: 2 October 2007 / Published: 25 March 2008

Keywords: 4-amino-3,5-di-(4-pyridyl)-4H-1,2,4-triazole, 3,5-di-(4-pyridyl)-1H-1,2,4-triazole, synthesis

\section{Introduction}

4-Amino-3,5-di-(4-pyridyl)-4H-1,2,4-triazole (1) and 3,5-di-(4-pyridyl)-1H-1,2,4-triazole (2) are potential multi-topic bridging ligands in preparation of coordination compounds of $1-3 \mathrm{D}$ structures.[1] In an early literature, a method to prepare compound 1 has been reported [2], which involves the reaction of isonicotinonitrile with excess amount of hydrazine in ethylene glycol at $130^{\circ} \mathrm{C}$. Polymeric copper complexes of 2 have been prepared by Chen et al.; $\mathbf{2}$ was generated by an in situ cycloaddition of 4-pyridylnitrile and ammonia in presence of $\mathrm{Cu}^{2+}$ under hydrothermal condition.[3] However, no synthetic procedures about the compound 2 - the deaminated product of $\mathbf{1}$ has appeared in the literature to the best of our knowledge. In this paper, we describe a facile method to prepare compound $\mathbf{2}$ starting from isonicotinic acid and hydrazine.

\section{Synthesis}

Isonicotinic acid $(2.46 \mathrm{~g}, 0.02 \mathrm{~mol})$ and $2 \mathrm{ml}$ of $80 \%$ hydrazine were mixed in a $15 \mathrm{ml}$ Teflon-lined reactor and heated for $48 \mathrm{~h}$ at $186^{\circ} \mathrm{C}$ [4]. The resulting liquid was diluted by water, and then the $\mathrm{pH}$ was adjusted from 9 to 6 by addition of $\mathrm{HCl}$ solution. White precipitate was obtained, and recrystallised from ethanol. The product is actually a mixture of 4-amino-3,5-di-(4-pyridyl)-4H-1,2,4-triazole (1) and 3,5-di-(4-pyridyl)-1H-1,2,4-triazole (2) in $c a$ 1:7 molar ratio, estimated from the HNMR spectrum.

Pure sample of $\mathbf{2}$ was prepared by a successive deamination process [5]. The mixture of $\mathbf{1}$ and $\mathbf{2}$ (2.38 g, ca 10 mmol) was dissolved in aqueous $\mathrm{HCl}(6 \mathrm{M}, 3 \mathrm{~mL})$. To it was added slowly an aqueous solution of $\mathrm{NaNO}_{2}(0.76 \mathrm{~g}$, $11 \mathrm{mmol}$ ); a lot of bubbles were generated quickly. The mixture was stirred for $5 \sim 6 \mathrm{~h}$, then the $\mathrm{pH}$ was adjusted from 4 to 6.5 by $10 \% \mathrm{NaOH}$ solution. White precipitate appeared and it was filtered and dried in air. Recrystallisation of the crude product from ethanol afforded colorless needles of $\mathbf{2}$. The overall yield of this method is $9 \%$. 
<smiles>Nn1c(-c2ccncc2)nnc1-c1ccncc1</smiles>

(1)

(2)<smiles>Nn1c(-c2ccncc2)nnc1-c1ccncc1</smiles>

(1)

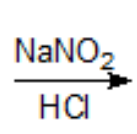<smiles>c1cc(-c2n[nH]c(-c3ccncc3)n2)ccn1</smiles>

(2)

Melting point: sublimated at $242^{\circ} \mathrm{C}$

IR (KBr pellet, $\mathrm{cm}^{-1}$ ): 1607 s, 1448 m, 1144 w, 983 m, 838 w, 724 m, 513 w.

${ }^{1}$ H-NMR (400 MHz, DMSO-d 6 ): $\delta=8.78(4 \mathrm{H}, \mathrm{d}, \mathrm{py}-\mathrm{H}), 8.02(4 \mathrm{H}, \mathrm{d}, \mathrm{py}-\mathrm{H})$.

Elemental Analysis: Calculated for $\mathrm{C}_{12} \mathrm{H}_{9} \mathrm{~N}_{5} \cdot 0.5 \mathrm{H}_{2} \mathrm{O}$ : C 57.59, H 4.83, N 27.98\%; Found: C 57.28, H 4.70, N $27.90 \%$.

MS (m/z): $225.2(15 \%), 224.2(100 \%, \mathrm{M}+\mathrm{H}), 218.3(5 \%)$.

\section{References}

1. Dong, Y.-B.; Wang, H.-Y.; Ma, J.-P.; Huang, R.-Q.; Smith, M. D. Cryst. Growth Des. 2005, 5, 789 - 800.

2. Bentiss, F.; Lagrenée, M.; Traisnel, M.; Mernari, B.; Elattari, H. J. Heterocyclic Chem. 1999, 36, 149 - 152.

3. Zhang, J.-P.; Lin, Y.-Y.; Huang, X.-C.; Chen, X.-M. J. Am. Chem. Soc. 2005, 127, 5495 - 5506.

4. Herbst, R. M.; Garrison, J. A. J. Org. Chem. 1953, 18, $872-877$.

5. Mosch-Zanetti, N. C.; Ferbinteanu M.; Magull, J. Eur. J. Inorg. Chem. 2002, 950 - 956.

(C) 2008 by MDPI (http://www.mdpi.org/). Reproduction is permitted for noncommercial purposes. 